\title{
Drought response and mitigation in Mediterranean irrigation agriculture
}

\author{
A. do Ó \& M. J. Roxo \\ Faculdade de Ciências Sociais e Humanas, \\ Universidade Nova de Lisboa, Portugal
}

\begin{abstract}
This paper identifies the most significant stakeholders involved in drought risk management at three irrigation perimeters, in the drought-prone southern Portuguese region of Alentejo. Key stakeholders were the target of tailored questionnaires and interviews, delivering their perception both of the natural drought hazard, of their exposure to risk, and of the plans and actions taken to mitigate it.

Based on enquiries results and literature review, stakeholders were analysed and classified according to their role and legal framework. First, relationships between them were drafted and analyzed in flow charts, depicting their hierarchical dependencies, the circulation of information, and the direction of recommendations and decisions. Particular attention was paid to the process of implementing drought preparedness and mitigation actions. Secondly, all legal tools framing and regulating the irrigation activity were analysed, assessing its role in managing drought risk and temporary water scarcity. The irrigation framework previously defined was then put into perspective, and integrated in the context of water, agricultural, and land management policies, assessing their levels of time, space and economic integration and effectiveness.

Preliminary results show that the process of implementing a new paradigm of water management, according to the objectives of the European Water Framework Directive, is underway. Nevertheless, the hydraulic paradigm that dominated water policies throughout the $20^{\text {th }}$ century remains dominant at the local and regional level. This gap results on a deficient application of current water policies, poorly transposed into effective irrigation farming regulation.
\end{abstract}

Keywords: drought response, Mediterranean irrigation, stakeholders' perception, legal instruments, Alentejo. 


\section{Introduction}

In the euro-Mediterranean region, droughts are a major natural hazard, mostly affecting the agricultural sector (Pereira et al. [1]). A research Project was recently launched in order to develop more appropriate tools for the identification, monitoring, characterisation and prediction of droughts in the southern Portuguese region of Alentejo, where agriculture suffers greatly from drought impacts. Particular attention was paid to three of the numerous Stateinitiative irrigation perimeters (Figure 1), which concentrate over a third of the irrigation farming in the region (INE [2]).

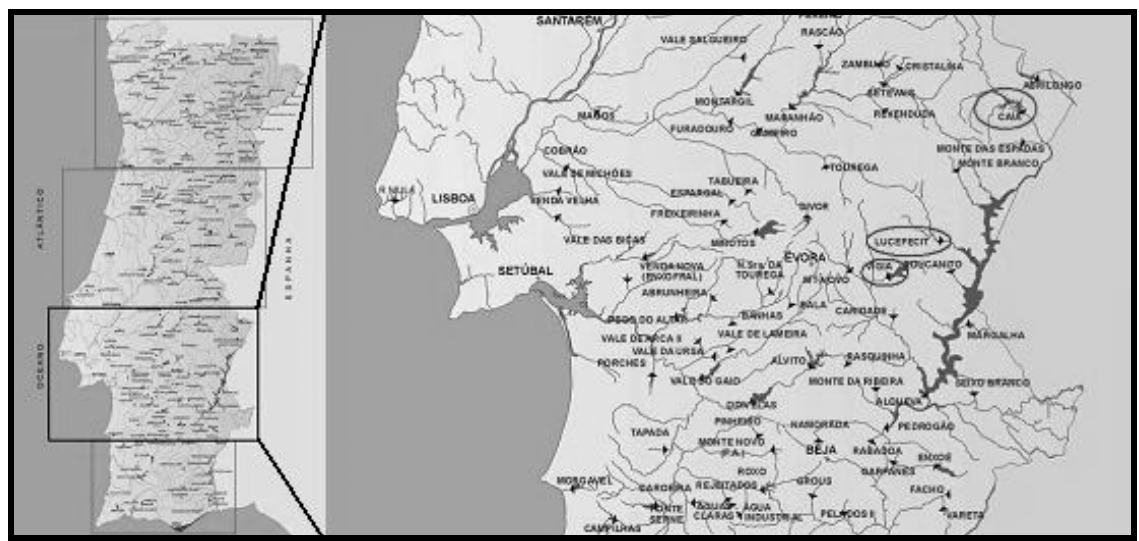

Figure 1: Location of the study area (source: http://cnpgb.inag.pt /gr_barragens/gbportugal/Mapaescolha.htm).

The irrigation perimeters of Vigia, Lucefecit and Caia are all part of the large irrigation scheme designed for the region in the mid $20^{\text {th }}$ century (called Plano de Rega do Alentejo, dating back to 1957). The Plan was created by the dictatorial regime that ruled Portugal between 1926 and 1974, and aimed to modernise agriculture based on irrigation, to grant food self-sufficiency to the nation, and to promote regional economy. The irrigation network designed over 50 years ago is only now being completed, along with the full implementation of the Alqueva Dam Project (the largest reservoir in the EU, built in 1998-2002), but supported the construction of several parts of the regional scheme, such as the three dams above mentioned, as well as many others depicted in Figure 1.

The main features of the perimeters of Vigia, Lucefecit and Caia are presented in Table 1, and albeit showing significant similarities in terms of geographic, social and economic background, they differ strongly in their dimension and recent evolution: while Vigia and Lucefecit are small-scale perimeters, quite aged in terms of both users and infrastructures, with poor development and innovation perspectives, and a more social significance rather than economic, the perimeter of Caia is larger, better equipped and modernised, 
with an increasing demand for land and water and renewed irrigation uses (Do Ó [3]). Furthermore, while the former two mostly supply water to individual farmers and/or family enterprises, the latter mainly supplies water to international food corporations.

Table 1: $\quad$ Main features of the case study irrigation perimeters (Do Ó [3]).

\begin{tabular}{|l|l|l|l|}
\hline \multicolumn{1}{|c|}{ Perimeter } & \multicolumn{1}{c|}{ Lucefecit } & \multicolumn{1}{c|}{ Vigia } & \multicolumn{1}{c|}{ Caia } \\
\hline First year & 1977 & 1976 & 1967 \\
\hline Net capacity & $9 \mathrm{hm}^{3}$ & $15,5 \mathrm{hm}^{3}$ & $192 \mathrm{hm}^{3}$ \\
\hline Irrigated area & $1.179 \mathrm{ha}$ & $1.505 \mathrm{ha}$ & $7.237 \mathrm{ha}$ \\
\hline Average size & $20 \mathrm{ha}$ & $13 \mathrm{ha}$ & $48 \mathrm{ha}$ \\
\hline Use rate & $46 \%$ & $70 \%$ & $81 \%$ \\
\hline Main crops & Corn, wheat & $\begin{array}{l}\text { Corn, sunflower, } \\
\text { olives, vines }\end{array}$ & $\begin{array}{l}\text { Corn, wheat, } \\
\text { tomato, olives, } \\
\text { sunflower }\end{array}$ \\
\hline
\end{tabular}

Table 2: $\quad$ Main institutional stakeholders involved in water management in the reservoirs of Vigia, Lucefecit and Caia.

\begin{tabular}{|l|l|l|}
\hline Institution & Hierarchy & Function \\
\hline $\begin{array}{l}\text { Instituto da Água } \\
\text { INAG) }\end{array}$ & $\begin{array}{l}\text { Central Public } \\
\text { Administration } \\
\text { (Ministry of } \\
\text { Environment) }\end{array}$ & $\begin{array}{l}\text { National Water Authority; } \\
\text { water resources policies, } \\
\text { planning and management }\end{array}$ \\
\hline $\begin{array}{l}\text { Administração da } \\
\text { Região Hidrográfica } \\
\text { do Guadiana (ARHG) }\end{array}$ & $\begin{array}{l}\text { Regional Public } \\
\text { Administration }\end{array}$ & $\begin{array}{l}\text { River basin planning, licensing } \\
\text { and management }\end{array}$ \\
\hline $\begin{array}{l}\text { Direcção-Geral de } \\
\text { Agricultura e de } \\
\text { Desenvolvimento } \\
\text { Rural (DGADR) }\end{array}$ & $\begin{array}{l}\text { Central Public } \\
\text { Administration } \\
\text { (Ministry of } \\
\text { Agriculture) }\end{array}$ & $\begin{array}{l}\text { Support agricultural } \\
\text { competitiveness and } \\
\text { sustainability; irrigation policies } \\
\text { and planning }\end{array}$ \\
\hline $\begin{array}{l}\text { Águas do Centro } \\
\text { Alentejo (ACA), } \\
\text { Águas do Norte } \\
\text { Alentejano (ANA) }\end{array}$ & $\begin{array}{l}\text { Public holding } \\
\text { utility enterprises }\end{array}$ & $\begin{array}{l}\text { Conceded management of } \\
\text { regional water supply and } \\
\text { sewage systems }\end{array}$ \\
\hline $\begin{array}{l}\text { Irrigators Associations } \\
\text { (IAs) of Vigia, } \\
\text { Lucefecit and Caia }\end{array}$ & $\begin{array}{l}\text { Local non- } \\
\text { governmental } \\
\text { organisations }\end{array}$ & $\begin{array}{l}\text { Conceded use and management } \\
\text { of irrigation perimeters }\end{array}$ \\
\hline
\end{tabular}

\section{Stakeholder identification}

The perimeters of Vigia, Lucefecit and Caia were built and implemented by the national public authorities, but its management has been conceded (in the 1990s) to local associations of irrigators and water users, under the legal custody of the 
ministerial department of Agriculture and Rural Development (DGADR Direcção-Geral de Agricultura e Desenvolvimento Rural). Although Irrigators Associations are allowed independent functioning and management of local infrastructures and resources, the State retains its legal property, controls internal regulations of the groups, and has the ultimate decision in extreme events, such as droughts and floods.

All three perimeters have their water source on the reservoirs bearing the same name, which are part of the public water domain, and any water abstraction or use is subject to previous authorisation from the recently created Guadiana river basin public authority (ARHG - Administração de Região Hidrográfica do Guadiana). Furthermore, water planning and management are subject to the overall regulation by the National Water Authority (INAG - Instituto da Água).

The main water user from these reservoirs, in global quantitative terms, is by far irrigation. The only other significant user is urban supply, through the water utility companies ACA - Águas do Centro Alentejo (in the case of Vigia) and ANA - Águas do Norte Alentejano (in the case of Caia), both part of the national water supply holding Águas de Portugal (AdP).

There are other minor institutional stakeholders, indirectly involved in the management of water stored in the reservoirs, namely those represented within the Dams Management Commission (CGA - Comissão de Gestão de Albufeiras), which is also presided by INAG. A synthesis of the main institutional stakeholders involved is presented in Table 2.

\section{Stakeholder analysis}

Although the operational response to a supply reduction due to drought conditions is mainly a responsibility of the local Irrigators Associations (IAs), it lies within the jurisdiction of DGADR, the national authority responsible for any decisions regarding public initiative irrigation perimeters. In this context, IAs usually restrict their action to the distribution or apportionment of water deficits among users, according to each farmer's area and culture type, based on rough empirical methods and subject to previous authorisation from DGADR.

During the drought period of 2004-06, when two of the case study perimeters (Vigia and Lucefecit) suffered significant supply reductions, most response measures were taken within the Dams Management Commission, and later in 2005 within the Drought Commission created by Governmental initiative. The latter allowed for improved circulation of data and information, and soundly based agreements between different sectors and water users. Still, as the Commission was top-down, reactive, and ad-hoc created, it was not sufficient either to reduce economic impacts, or even to avoid conflict between the local Irrigators Association and the Water Utility Company (ACA, in Vigia): a law suit and court process opposing the two users was then initiated, and has not yet been solved. The dispute refers to the payment of water used by ACA for urban supply, which according to the local IA, who had restricted access to water in both 2005 and 2006, is still due. 
Furthermore, the Drought Commission had no significant public participation procedures, which are particularly difficult to achieve within such crisis management structures. It did produce some important final recommendations (before extinction), but so far these have not been implemented: they included the need for contingency planning for each public water source, and the creation of a permanent system for drought observation, monitoring, follow-up and prediction.

In order to reach an in-depth assessment of the role of different stakeholders, a set of questionnaires was drawn: one enquiry targeted at individual irrigators, and tailored interviews targeted at the most important decision-makers. These questionnaires allowed as well for a better understanding to be gained of the stakeholders' perception of local drought hazard, of their exposure to risk, and of the plans, policies and actions taken to mitigate it. Such perception is crucial to fully understand the position and orientation of stakeholders, amidst the global structure of drought risk management in the area.

The enquiries were launched based on a $20 \%$ sample, representative of the population of effective irrigators in the perimeters of Vigia, Lucefecit, and Caia, during the 2008 campaign. The sample was based on four classes of property dimension, and each proportion was calculated as the average between the relative number of farmers and irrigated area within each class. The sample was also stratified according to the irrigators' age and qualification, and the final selection of individuals was intentional, according to the snow-ball nonprobabilistic method (Goodman [4]). Fieldwork was conducted between October 2008 and February 2009, with a total of 46 enquiries applied.

The results show that:

a. The water supplied has a significantly high cost for most farmers (between 20 and $50 \%$ of all operational costs), namely among the smaller properties and more traditional cultures (corn, wheat, vegetables);

b. A majority of farmers ( $72 \%)$ has no alternative water source; only at Vigia and among larger properties such sources have a significant importance, namely small earth dams $(19 \%)$ and direct abstraction from streams $(13 \%)$;

c. At the two perimeters affected by the 2004-06 drought, it was naturally the best remembered event (81\% at Vigia and $78 \%$ at Lucefecit), but in Vigia the 1991-95 event is also well kept in memory (63\%); at Caia, where the 2004-06 drought caused no restrictions, the best remembered events were 2000-01 (52\%) and 1994-95 (33\%);

d. The impacts reported by farmers were quite diverse, but mainly relate to losses in production (41\%), and opting out certain annual cultures (28\%); at Caia, $43 \%$ referred no impacts, mostly among the many who have only recently installed their activity;

e. The most common mitigation measures were operational, such as shifting from water intensive to less water demanding crops ( $24 \%$, typically from corn to sunflower or others), and anticipating harvest (17\%, especially at Vigia); at Lucefecit, the less renewed perimeter, only 1 out of 9 enquiries reported any mitigation action being taken; 
f. Only $39 \%$ of all enquiries recall any mitigation action being taken by the Public Administration, mostly water saving campaigns (17\%), and financial support measures (24\%, with $13 \%$ low-interest loans and $11 \%$ bank warranties);

g. The main causes of drought and associated water scarcity reported were natural climate variability ( $80 \%)$ and induced climate change (37\%), with the latter weighting more at Caia (52\%) and less at Lucefecit (11\%);

h. According to the enquiries, the main solution that ought to be adopted is the construction of appropriate infrastructures $(65 \%)$, especially at Lucefecit (89\%) and Vigia (81\%), where a significant proportion refers to diverting water from the neighbouring Alqueva dam (56\% and 38\% respectively); at Caia, besides infrastructure construction (43\%), it was also mentioned the reduction of water losses and waste (19\%), and direct abstraction from neighbouring river Guadiana (14\%).
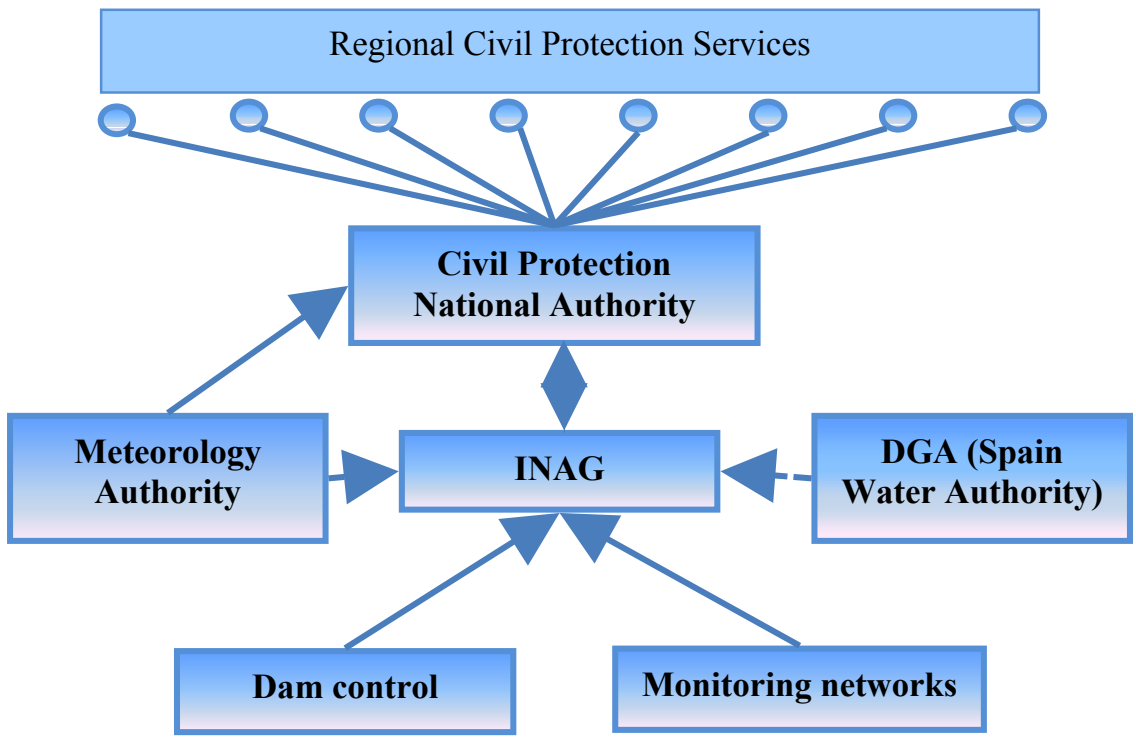

Figure 2: Drought monitoring institutional information flowchart.

These results highlight the differences between the smaller and more traditional perimeters of Vigia and Lucefecit, where social objectives seem more significant than economic ones, and that of Caia, where demand for irrigation land rose abruptly during the last few years, mainly for the plantation of intensive olive groves and other industrial cultures (tomato, sunflower). This trend has mostly been pushed by Spanish or Spain-based multinational agroindustrial companies, benefiting from the border vicinity and improved accessibility location.

Results from tailored interviews to decision makers added further insight into the relations among stakeholders involved, regarding drought occurrence and 
response. Eight interviews were conducted between October 2008 and February 2009 to major representatives of the institutions previously referred to in Table 2 . The information collected was thoroughly analysed and allowed to depict the information flows between institutions regarding drought monitoring (Figure 2), and the decision flows covering drought response (Figure 3).

Figure 2 shows how INAG, the National Water Authority, centralizes all information regarding drought monitoring. This includes the process of declaring a drought situation that may trigger the creation of a formal response structure, such as the Drought Commission formed by governmental decree in 2005.

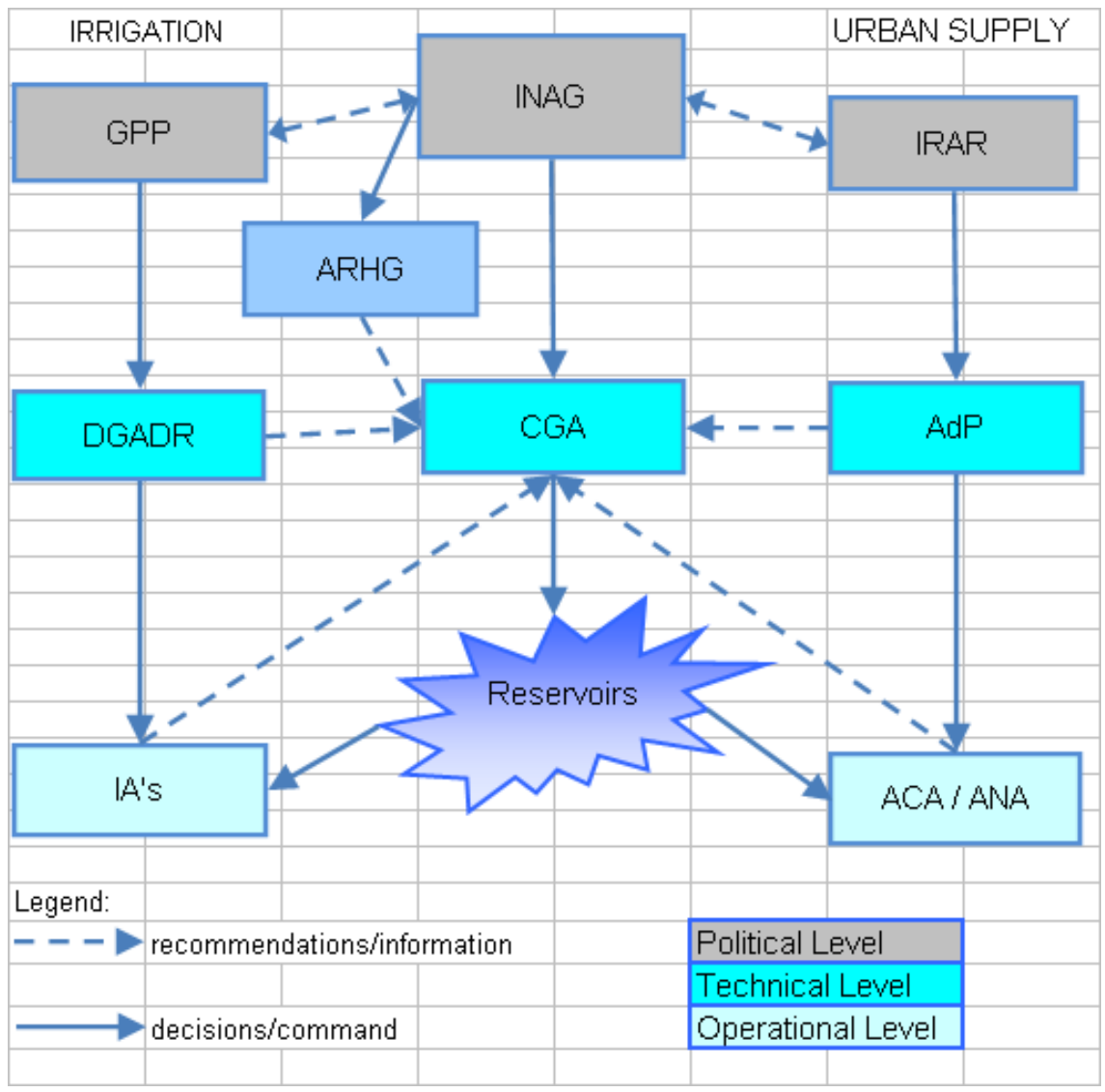

Figure 3: Drought response institutional decision flowchart.

On the other hand, Figure 3 shows how INAG remains central on a response process, but along with the sectorial structures that regulate the users' activity (irrigation, and urban supply). The cross-sectorial facility is the Dams Management Commission (CGA), participated by most of the stakeholders depicted, but INAG retains the final decision through its presidency. It is this Commission's responsibility (or the Drought Commission, in particular drought 
crisis situations such as occurred in 2004-06), to decide on supply restrictions or other measures to mitigate and respond to drought impacts, affecting water users.

The River Basin Authority (ARHG) is about to play a more significant role, as it is entitled to plan, license and control all water uses in the basin, but its responsibility in drought situations remains unclear. Nevertheless, it is expected to assume some of the responsibilities previously assigned to INAG, in a long awaited decentralisation process.

Table 3: Major policies related to drought risk management in the stateinitiative irrigation perimeters of Alentejo.

\begin{tabular}{|l|l|l|}
\hline Instrument & $\begin{array}{l}\text { Geographic } \\
\text { scope }\end{array}$ & Drought management scope \\
\hline $\begin{array}{l}\text { CAP - Common } \\
\text { Agricultural Policy }\end{array}$ & EU & $\begin{array}{l}\text { Environmental conditioning, } \\
\text { including water use efficiency }\end{array}$ \\
\hline $\begin{array}{l}\text { PEN - National } \\
\text { Develogic Plan for Rural }\end{array}$ & Portugal & $\begin{array}{l}\text { Financing more efficient } \\
\text { irrigation and consume- } \\
\text { control systems; supporting } \\
\text { the improvement of state- } \\
\text { initiative irrigation perimeters }\end{array}$ \\
\hline $\begin{array}{l}\text { PRODER - Rural } \\
\text { Pevelopment }\end{array}$ & Portugal & $\begin{array}{l}\text { Financing more efficient } \\
\text { irrigation systems, monitoring } \\
\text { consumption, and increasing } \\
\text { surface water retention }\end{array}$ \\
\hline $\begin{array}{l}\text { WFD - Water } \\
\text { Framework Directive }\end{array}$ & EU & $\begin{array}{l}\text { General political guidance and } \\
\text { regulation }\end{array}$ \\
\hline $\begin{array}{l}\text { Portuguese-Spanish } \\
\text { Albufeira Convention }\end{array}$ & Iberian river & $\begin{array}{l}\text { Strategic water policies; bi- } \\
\text { lateral cooperation; flow } \\
\text { regime }\end{array}$ \\
\hline Water Law & Portugal & $\begin{array}{l}\text { Transposes the WFD; } \\
\text { planning and management } \\
\text { guidelines }\end{array}$ \\
\hline $\begin{array}{l}\text { National Water Plan } \\
\text { regulations }\end{array}$ & Portugal & $\begin{array}{l}\text { Thematic technical analysis; } \\
\text { river basin planning } \\
\text { guidelines }\end{array}$ \\
\hline $\begin{array}{l}\text { National Programme } \\
\text { for an Efficient Water } \\
\text { Use }\end{array}$ & Portugal & $\begin{array}{l}\text { Political guidance; operational } \\
\text { objectives }\end{array}$ \\
\hline River Basin Plans & Guadiana river \\
basin & $\begin{array}{l}\text { Regional objectives; } \\
\text { operational planning and } \\
\text { management }\end{array}$ \\
\hline Caia & $\begin{array}{l}\text { Supply reduction operational } \\
\text { management, field assistance }\end{array}$ \\
\hline
\end{tabular}




\section{Policy analysis}

A primary result from the research project covering the present work was previously published by the first author (Do Ó [3]), identifying and analysing the role of all legal instruments related to water and drought risk management at the irrigation perimeters. According to the author, irrigation activity and drought risk management at the perimeters of Vigia, Lucefecit and Caia are legally framed by a set of policies, briefly described in Table 3 .

The diversity of policies involved in the management of drought risk within these irrigation perimeters, is a result of the absence of drought management plans, or even contingency plans within each perimeter.

CAP principles and guidelines are implemented through measures programmed in the frame of national instruments applying European agricultural funds in Portugal (PEN and PRODER, referred to in Table 3). These measures embody the objectives of reducing water losses and increasing its efficient use, as foreseen in most of the water policy tools presently enforced (also referred to in Table 2). In the absence of specific drought management plans, policy guidance is provided by these instruments, hence their importance.

New River Basin Management Plans (RBMPs), which ought to be operational by 2010, may include a specific Drought Management Plan (DMP), based on the guidelines proposed by the European Commission in the frame of the 2007 Communication on Water Scarcity and Droughts (EC [5]). The final decision remains assigned to INAG, although the process leading to a new RBMP is supervised by ARHG, and publicly participated (including a transboundary component with Spain).

If created and approved, such DMP should include (EC [5]):

- Indicators and thresholds establishing onset, ending, and severity levels of the exceptional circumstances (prolonged drought);

- Measures to be taken in each drought phase in order to prevent deterioration of water status and to mitigate negative drought effects;

- Organizational framework to deal with drought and subsequent revision and updating of the existing drought management plan.

The Plan may as well constitute a major opportunity to reflect the environmental conditioning proposed under the recent CAP revision (CEC [6]), and to integrate the new flow regime agreed upon in 2008, in the frame of the Albufeira Convention regulating water uses in river basins shared between Portugal and Spain (AR [7]).

\section{Conclusions}

The research conducted puts in evidence several aspects related specifically to the case study, and others in the frame of drought risk management under Mediterranean conditions.

The three irrigation perimeters present a very different degree of drought vulnerability, namely between the large and intensively used Caia scheme, and the small decaying perimeters of Vigia and Lucefecit. Nevertheless, increasing 
pressure and water demand in Caia may soon pose supply problems, as well as conflicts between users, as recently occurred in Vigia.

Both the information and the decision institutional flows remain much centred in one single national institution (INAG), with little participation from other stakeholders. The flows are also strongly separate in sectors, with little integration between the two major users: irrigation, and urban supply.

The number and diversity of policies involved in drought risk management is a consequence of the absence of specific river basin Drought Management Plans. These are considered and foreseen in the frame of the European Water Framework Directive, a process that is undergoing and aiming to implement a new paradigm of water management. Together with the new Common Agricultural Policy, these have been the major driving forces pushing irrigation farming towards a more efficient use of water.

Nevertheless, the hydraulic paradigm that dominated water policies in the region throughout the $20^{\text {th }}$ century, remains dominant at the local level. This gap, together with significant knowledge shortages in both local water supply and demand, and lack of local stakeholders' empowerment, results on a deficient application of current water policies, poorly transposed into the technical tools regulating irrigation farming. This situation is particularly serious during drought events, when crisis reactive approaches dominate over preventive, proactive and risk-oriented ones.

\section{References}

[1] Pereira, L.S., Cordery, I. \& Iacovides, I., Coping with water scarcity, Technical Documents in Hydrology, Vol. 58, UNESCO: Paris, 2002.

[2] INE - Instituto Nacional de Estatística, Inquérito à Estrutura das Explorações Agrícolas 2005, INE: Lisboa, 2006.

[3] Do Ó, A., Instrumentos de Planeamento e Gestão do Risco de Seca nos Aproveitamentos Hidroagrícolas do Sul de Portugal, Proceedings of the $6^{\circ}$ Congresso Ibérico sobre Gestão e Planeamento da Água, Fundação Nova Cultura da Água / Bakeaz: Vitoria / Gasteiz (Spain), 2008.

[4] Goodman, A.L., Snowball Sampling. The Annals of Mathematical Statistics, 32, pp. 148-170, 1961.

[5] EC - European Communities, Drought Management Plan Report, Water Scarcity and Droughts Expert Network / Technical Report 2008 - 023, Office for Official Publications of the European Communities: Luxembourg, 2007.

[6] CEC - Commission of the European Communities, Communication from the Commission to the European Parliament and the Council preparing for the "Health Check" of the CAP Reform, COM (2007) 722 final, November 20th 2007.

[7] AR - Assembleia da República, Resolução que aprova o Protocolo de Revisão da Convenção de Albufeira, RAR 62/2008, Diário da República, $1^{\text {a }}$ série, $\mathrm{n}^{\circ} 222$, de 14 de Novembro de 2008. 